\title{
PENERAPAN METODE PEMBELAJARAN KOOPERATIF BERBANTUAN MEDIA GAME PUZZLE UNTUK MENINGKATKAN MOTIVASI BELAJAR DAN PEMAHAMAN BELAJAR SISWA PADA MATA PELAJARAN KANTOR DEPAN (RESERVASI)
}

\author{
Luh Suardani
}

\author{
SMK Negeri 2 Singaraja \\ Email: suardani.luh@gmail.com
}

\begin{abstract}
ABSTRAK
Tujuan dari diadakannya penelitian ini adalah untuk mengetahui peningkatan motivasi belajar dan pemahaman belajar siswa pada mata pelajaran kantor depan (reservasi) Kelas XI AP4 SMK Negeri 2 Singaraja semester ganjil tahun pelajaran 2016/2017 setelah diterapkannya metode pembelajaran kooperatif berbantuan media game puzzle. Penelitian ini adalah penelitian tindakan kelas (PTK). Subjek dalam penelitian tindakan kelas ini adalah siswa kelas XI AP 4 SMK Negeri 2 Singaraja dengan jumlah siswa 40 orang terdiri dari 17 orang siswa laki-laki dan 23 orang siswa perempuan. Sedangkan objeknya adalah motivasi belajar dan pemahaman belajar siswa. Data motivasi belajar siswa dikumpulkan dengan angket/kuesioner, sedangkan data pemahaman belajar siswa dikumpulkan dengan tes. Analisis data yang digunakan pada penelitian ini menggunakan analisis data deskriptif. Berdasarkan analisis data yang dilakukan dapat disimpulkan bahwa penerapan metode pembelajaran kooperatif berbantuan media game puzzle dapat meningkatkan motivasi belajar dan pemahaman belajar siswa pada mata pelajaran kantor depan (reservasi) kelas XI AP4 SMK Negeri 2 Singaraja semester ganjil tahun pelajaran 2016/2017.
\end{abstract}

Kata kunci: metode pembelajaran kooperatif, media game puzzle, motivasi belajar, pemahaman belajar siswa

\begin{abstract}
The purpose of this research was to find out the increase in learning motivation and students' understanding of the front office subjects (reservation) of Class XI AP4 of Singaraja State Vocational High School 2 semester 2016/2017 after the implementation of cooperative learning methods assisted by media puzzle games. This research is classroom action research. The subjects in this class action research were students of class XI AP 4 of SMK Negeri 2 Singarja with 40 students consisting of 17 male students and 23 female students. While the object is learning motivation and understanding of student learning. Data on student learning motivation was collected by questionnaire, while data on students' learning comprehension was collected by tests. Data analysis used in this study used descriptive data analysis. Based on the data analysis conducted it can be concluded that the application of cooperative learning methods assisted by puzzle media can increase learning motivation and students' learning comprehension on front office subjects (reservations) in class XI AP4 Singaraja State Vocational School 2 semester odd 2016/2017 academic year.
\end{abstract}

Keywords: cooperative learning methods, puzzle game media, learning motivation, understanding of student learning 


\section{PENDAHULUAN}

Pendidikan merupakan suatu kebutuhan yang paling utama dan terpenting saat ini bagi kehidupan manusia. Pendidikan adalah pilar utama dalam pembentukan mental/ karakter seorang siswa. Pendidikan yang baik akan membentuk mental atau karakter siswa yang lurus dan terarah. Pembinaan mental yang baik pada akhirnya akan bermuara pada kebaikan di kehidupan yang akan datang. Pendidikan memegang peranan penting dalam meningkatkan mutu atau kualitas serta daya saing suatu bangsa atau negara. Kehidupan di era globalisasi ini yang penuh dengan tantangan, persaingan dan ketidakpastian yang disertai perkembangan IPTEK yang cukup pesat menuntut semua pihak untuk melakukan peningkatan mutu di berbagai aspek dalam menyikapi masalah-masalah tersebut. Untuk itu perlu adanya untuk meningkatkan mutu dari suatu pendidikan.

Untuk meningkatkan mutu pendidikan, pemerintah telah menerapkan berbagai upaya diantaranya, melalui Departemen Pendidikan Nasional pada tahun 2007 telah melaksanakan program sertifikasi guru secara bertahap. Sertifikasi merupakan perwujudan dari UU No 14 tahun 2005 dan PP No 19 tahun 2005 dengan tujuan untuk meningkatkan kualitas mutu pendidikan. Selain itu, tentunya diperlukan tenaga pendidik/guru yang profesional, sebab guru merupakan salah satu unsur pendidikan yang memegang peranan penting dalam proses belajar-mengajar. Sebagai guru professional, hendaknya harus memiliki kemampuan mengajar, melatih serta mendidik yang baik. Salah satu usaha yang dapat ditempuh untuk meningkatkan profesionalisme seorang guru adalah dengan melakukan pendidikan serta pelatihan yang bertujuan untuk mengetahui kemampuan guru dalam melakukan kegiatan pembelajaran. Jika seorang guru atau pendidik tidak berhasil mengembangkan potensi peserta didik maka negara itu tidak akan maju, sebaliknya jika guru atau pendidik berhasil mengembangkan potensi peserta didik, maka terciptalah manusia yang cerdas, terampil, dan berkualitas. Menurut Wina Sanjaya (2006:19), peran guru adalah: "Sebagai sumber belajar, fasilitator, pengelola, demonstrator, pembimbing, dan evaluator". Sebagai sumber belajar dan motivator guru harus mampu meningkatkan pemahanan dan membangkitkan motivasi siswa agar aktivitas proses pembelajaran berhasil dengan baik. Salah satu cara untuk meningkatkan motivasi belajar dan pemahaman siswa dalam proses pembelajaran adalah dengan mengganti model pembelajaran yang selama ini tidak diminati lagi oleh siswa, seperti pembelajaran yang dilakukan dengan ceramah dan tanya-jawab, model pembelajaran ini membuat siswa jenuh dan tidak kreatif. Suasana belajar mengajar yang diharapkan adalah menjadikan siswa sebagai subjek yang berupaya menggali sendiri, memecahkan sendiri masalah-masalah dari suatu konsep yang dipelajari, sedangkan guru lebih banyak bertindak sebagai motivator dan fasilitator. Situasi belajar yang diharapkan di sini adalah siswa yang lebih aktif.

Fenomena seperti diatas merupakan permasalahan yang perlu segera ditemukan alternatif-alternatif pemecahannya. Salah satu upaya yang dapat dijadikan alternatif pemecahan masalah tersebut adalah dengan menerapkan pembelajaran yang meningkatkan motivasi belajar dan pemahaman belajar siswa melalui "Penerapan Metode Pembelajaran kooperatif berbantuan media game puzzle" pada mata pelajaran reservasi yang merupakan salah satu mata pelajaran produktif yang ada di SMK pariwisata, pada dasarnya Sekolah Menengah Kejuruan menciptakan peserta didik yang siap kerja, dalam upaya menyiapkan peserta didik yang handal dan memiliki kesiapan kerja, mereka dibekali dengan beberapa mata diklat yang dikelompokan menjadi 3 program yaitu program normatif, program adaptif, dan program produktif. Program produktif adalah kelompok mata diklat yang berfungsi membekali peserta didik agar memiliki kompetensi kerja sesuai Standar Kompetensi Kerja Nasional Indonesia (SKKNI).

SMK Negeri 2 Singaraja merupakan salah satu sekolah yang bergerak dalam bidang kejuruan. Ada 5 paket keahlian yang terdapat di sekolah ini, diantaranya Akomodasi Perhotelan, Tata Boga, Tata Kecantikan Kulit, Tata Kecantikan Rambut dan Tata Busana. Akomodasi perhotelan merupakan salah satu 
paket keahlian yang mempelajari bagaimana menjadi seorang pelaku pariwisata termasuk sebagai staff hotel yang baik. Di dalam paket keahlian ini, terdapat mata pelajaran kantor depan yang diberikan di kelas XI dan kelas XII.

Dalam melakukan kegiatan proses belajar mengajar, penulis menemukan beberapa permasalahan yang dialami oleh siswa. Permasalahan tersebut penulis temukan pada kelas XI AP4, yaitu banyak siswa yang sering tidak hadir dalam pembelajaran kantor depan dan pemahaman siswa terhadap materi ajar kantor depan khususnya dalam kompetensi dasar jenis-jenis kamar sedikit terhambat, dimana siswa sering mengalami kebingungan dalam membedakan jenis-jenis kamar berdasarkan fasilitas, lokasi dan tempat tidurnya.

Berdasarkan dari permasalahan tersebutlah, penulis mencoba untuk menawarkan solusi pembelajaran kepada siswa kelas XI AP4 dalam mata pelajaran kantor depan (reservasi), yaitu dengan memberikan siswa penerapan metode pembelajaran kooperatif berbantuan media game puzzle. Dalam metode pembelajaran kooperatif berbantuan media game puzzle ini, dilaksanakan dengan cara membentuk kelompok terlebih dahulu yang terdiri dari 8 orang untuk tiap kelompoknya, kemudian pendidik membagikan kepingan-kepingan gambar/puzzle untuk selanjutnya disusun oleh siswa sehingga ditemukanlah materi yang akan dibahasnya.

Penerapan metode pembelajaran kooperatif berbantuan media game puzzle diharapkan mampu meningkatkan motivasi peserta didik dalam mengikuti pembelajaran dan mampu untuk membantu siswa dalam memahami suatu materi ajar di kelas pada mata pelajaran kantor depan (reservasi) khususnya pada kompetensi dasar jenis-jenis kamar. Berdasarkan pembahasan diatas, mata pelajaran Kantor Depan (reservasi) sangat penting bagi peserta didik guna mengenal dasar dari pariwisata. Melalui kegiatan ini, penulis berharap dapat membantu memecahkan permasalahan diatas dengan "Penerapan Metode Pembelajaran Kooperatif Berbantuan Media Game Puzzle Untuk Meningkatkan Motivasi Belajar dan Pemahaman Belajar Siswa pada Mata Pelajaran Kantor Depan (Reservasi) Kelas XI AP4 SMK Negeri 2 Singaraja Semester Ganjil Tahun Pelajaran 2016/2017”.

\section{METODE PENELITIAN}

Penelitian tindakan kelas ini dilaksanakan di SMK Negeri 2 Singaraja Lokasinya di Jalan Srikandi No. 9 Singaraja. Penelitian tindakan kelas ini kurang lebih dilaksanakan selama satu semester dimulai sejak minggu ketiga bulan Agustus sampai akhir bulan Nopember 2016 .

Subyek yang dijadikan sumber data dalam penelitian tindakan kelas ini adalah siswa kelas XI AP 4 SMK Negeri 2 Singarja dengan jumlah siswa 40 orang terdiri dari 17 orang siswa laki-laki dan 23 orang siswa perempuan. Penelitian Mata Pelajaran reservasi pada materi jenis - jenis kamar dengan menggunakan metode pembelajaran kooperatif berbantuan media game puzzle.

Berdasarkan observasi awal yang telah dilakukan, model pembelajaran yang akan digunakan adalah metode pembelajaran kooperatif berbantuan media game puzzle, dengan metode berbantuan game puzzle yang merupakan bentuk permainan yang menantang daya kreatifitas dan ingatan siswa lebih mendalam dikarenakan munculnya motivasi untuk senantiasa mencoba memecahkan masalah, namun tetap menyenangkan sebab bisa diulang -ulang. Tantangan dalam permainan ini akan akan selalu memberikan efek ketagihan untuk selalu mencoba, mencoba dan terus mencoba hingga berhasil. Jenis puzzle yang digunakan adalah The letter readiness puzzle, yakni puzzle yang berupa gambar - gambar yang disertai dengan huruf - huruf nama gambar tersebut, tetapi huruf itu belum lengkap.

Penelitian ini akan dilaksanakan dalam 2 siklus pembelajaran. Dimana masingmasing siklus pembelajaran terdiri dari empat tahap tindakan yaitu tahap perencanaan tindakan, pelaksanaan tindakan, observasi tindakan, dan tahap refleksi. Hasil refleksi digunakan sebagai penyempurnaanpenyempurnaan tindakan untuk siklus berikutnya, sedangkan refleksi yang digunakan pada siklus terakhir digunakan untuk membuat suatu rekomendasirekomendasi dari hasil peneitian ini. 


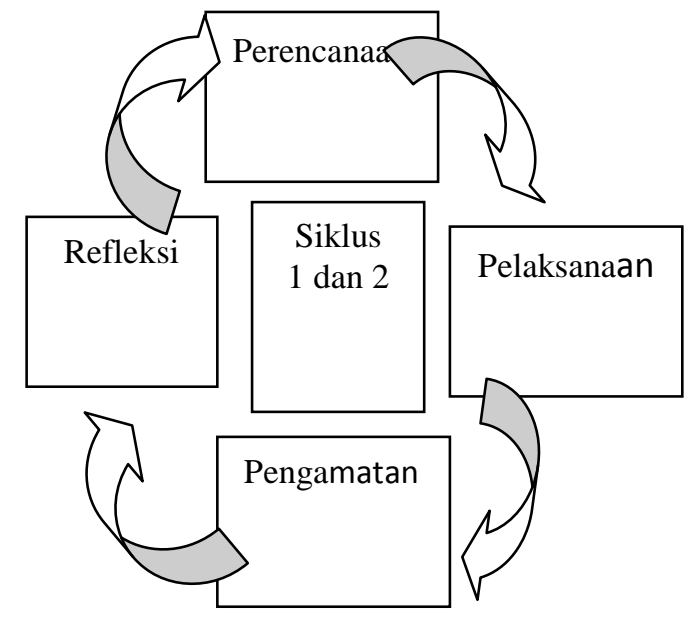

\section{Gambar 1. Siklus PTK}

Untuk mengukur motivasi belajar siswa pada mata pelajaran kantor depan mengenai jenis-jenis kamar dilakukan dengan menggunakan lembar angket/kuesioner motivasi belajar siswa yang telah dipersiapkan. Sedangkan untk mengukur pemahaman belajar siswa menggunakan tes. Tes dilakukan kepada siswa beberapa menit sebelum jam pelajaran berakhir yaitu dengan diberikan post test. Data dari test ini untuk memperkuat data yang telah diperoleh berdasarkan lembar observasi.

Setelah data motivasi belajar dan pemahaman belajar siswa terkumpul, selanjutnya dilakukan analisis data dengan menggunakan analisis deskriptif.

\section{HASIL DAN PEMBAHASAN \\ Hasil Penelitian}

Sebelum penelitian tindakan kelas ini dilaksanakan, peneliti mengadakan observasi dan pengumpulan data dari kondisi awal kelas yang akan diberikan tindakan, yaitu kelas XI AP 4 SMK Negeri 2 Singaraja semester ganjil tahun pelajaran 2016/2017.

Kondisi awal ini perlu diketahui agar kiranya penelitian ini sesuai dengan apa yang diharapkan oleh peneliti, apakah benar kiranya kelas ini perlu diberi tindakan yang sesuai dengan apa yang akan diteliti oleh peneliti yaitu penerapan metode pembelajaran kooperatif berbantuan media game puzzle untuk meningkatkan motivasi belajar dan pemahaman belajar siswa dalam menjelaskan/merangkai gambar jenis - jenis kamar tamu pada mata pelajaran reservasi.

Untuk mengungkapkan kondisi awal dari kelas yang menjadi objek tindakan kelas ini maka peneliti melakukan langkah-langkah sebagai berikut:

1. Perencanaan

Untuk mengetahui kondisi awal dari kelas XI AP 4 SMK Negeri 2 Singaraja semester ganjil tahun pelajaran 2016/2017, maka terlebih dahulu peneliti merencanakan observasi kegiatan belajar mengajar yang dilakukan di kelas XI AP 4 pada saat mata pelajaran reservasi berlangsung. Observasi ini dilakukan untuk mengetahui motivasi belajar dan pemahaman siswa dengan menggunakan penerapan metode pembelajaran yang pada umumnya di gunakan oleh guru, yaitu metode pembelajaran ceramah.

2. Pelaksanaan

Pelaksanaan ini untuk mengukur kemampuan awal siswa, di awali dengan pengajaran yang dilakukan oleh guru mata pelajaran reservasi dengan menggunakan metode pembelajaran ceramah. Pada pembelajaran ini peneliti mengamati kejadiankejadian yang terjadi secara rinci pada saat guru menyampaikan materi pelajaran dan pada akhir pelajaran guru memberikan soal post test sebagai alat evaluasi.

3. Hasil pengamatan

Berdasarkan observasi yang dilakukan oleh peneliti didapatkan bahwa pada pengajaran yang dilakukan, guru masih menggunakan cara pengajaran yang tradisional yaitu dengan menggunakan metode pembelajaran ceramah. Pada pembelajaran berlangsung terlihat siswa asik dengan kegiatannya sendiri yang tidak ada kaitannya dengan apa yang disampaikan oleh guru. Terlihat peserta didik bermain-main dengan temannya tanpa memperdulikan apa yang disampaikan oleh guru pengajar.

hasil tes yang dikerjakan oleh siswa pada soal post test yang telah dirancang oleh guru, setelah diadakan koreksi maka didapatkan hasil yang kurang memuaskan. Hasil koreksi tes awal dari 40 siswa yang ada di kelas XI AP 4 tersebut didapatkan hasil, 17 siswa mendapatkan nilai di bawah KKM, sedangkan siswa yang telah tuntas atau yang telah 
mendapatkan nilai di atas KKM berjumlah 23 siswa. Dari paparan hasil nilai yang didapatkan siswa, tampak bahwa yang mencapai ketuntasan belajar hanya 23 siswa atau hanya $77,85 \%$ dari jumlah siswa yang ada di kelas XI AP 4.

\section{Refleksi}

Bertolak dari kondisi awal dimana setelah diadakan post test, jumlah persentase siswa hanya $65.2 \%$, maka perlu diadakan suatu tindakan untuk meningkatkan motivasi belajar dan pemahaman belajar siswa pada mata pelajaran reservasi. Berdasarkan kondisi awal, maka peneliti merencanakan tindakan penelitian dengan menerapkan metode pembelajaran kooperatif berbantuan media game puzzle di kelas XI AP 4 SMK Negeri 2 Singaraja.

\section{Pembahasan Hasil Penelitian}

Berdasarkan penelitian yang dilakukan pada siklus I dengan menerapkan pembelajaran kooperatif berbantuan media game puzzle, terlihat bahwa siswa antusias dalam mengerjakan tugas-tugas yang diberikan oleh guru. Pada pengerjaan tugas kelompok ini tidak terlihat adanya siswa yang bermain-main ataupun asyik mengerjakan pekerjaan yang lain, semuanya fokus dalam mengerjakan tugas masing-masing. Pada pelaksanaan kegiatan kerja kelompok tampak adanya siswa yang mengalami kesulitan dalam mengerjakan tugas dan untuk mengatasi kesulitannya tersebut mereka bertanya kepada ketua kelompok yang berperan sebagai kooperatif berbantuan media game puzzle yang tugasnya membantu dan menjelaskan kesulitan yang dihadapi temannya. Namun ada pula siswa yang mengalami hambatan dalam mengerjakan tugas tersebut langsung bertanya kepada peneliti dan guru pengajar.

Pada post tes yang diberikan setelah dikoreksi oleh peneliti didapatkan hasil sebagai berikut: dari 40 siswa yang ada, 17 siswa mendapatkan nilai kurang dari 80 yang artinya nilainya masih di bawah KKM atau belum tuntas, sedangkan 23 siswa telah mendapatkan nilai diatas KKM atau telah tuntas,

Dengan melihat titik lemah yang terjadi pada sebagian kecil siswa berkenaan konsep dasar mengenai jenis - jenis kamar tamu. Maka perlu diadakan penjelasan yang mendasar pada anak-anak yang mengalami hambatan terutama dalam membedakan jenis - jenis kamar.

Perlu dibentuk kelompok-kelompok kecil yang terdiri dari 4 orang siswa. Untuk berkolaborasi dalam belajar dan dipimpin oleh siswa yang memiliki kemampuan lebih dan mampu menyampaikan materi yang dikuasainya dan juga perlu dibuat suatu catatan-catatan dasar yang siswa sering salah dalam membedakan jenis - jenis kamar berdasarkan fasilitas, berdasarkan tempat tidur, berdasarkan letak, untuk ditindak lanjuti pada tindakan berikutnya.

Pada siklus II dilakukan beberapa perbaikan untuk mengatasi kelemahan yang terlihat pada siklus I. Pada tindakan di siklus II diawali penjelasan kepada siswa tentang prosedur yang akan dilaksanakan pada pembelajaran untuk kelompok kecil.

Peneliti membagi menjadi 10 kelompok yang terdiri dari 4 orang siswa, dan siswa berkumpul menurut kelompoknya masingmasing. Setelah siswa berkumpul dengan kelompoknya maka peneliti membagikan potongan/kepingan gambar jenis - jenis kamar yang harus dikerjakan oleh setiap anggota kelompok dan didiskusikan bersama dari masing-masing kelompok dengan kegiatan sebagai berikut.

a. Guru menyampaikan materi mengenai jenis - jenis kamar tamu

b. Guru memberi penjelasan umum tentang materi yang akan dibahas kepada peserta didik.

c. Kelas dibagi ke dalam kelompok kecil, yaitu terdiri dari 4 orang peserta didik dan diusahakan kelompok yang dibentuk tersebut adalah kelompok yang heterogen.

d. Guru membagikan potongan/kepingan (puzzle) jenis -jenis kamar ke setiap kelompok

e. Guru memonitoring dan membimbing terus peserta didik yang lain membutuhkan bimbingan. Guru memonitoring dengan berkunjung dan menanyakan kesulitan yang dihadapi 
setiap kelompok pada saat mereka diskusi maupun praktik di kelas.

f. Jika ada masalah, guru memberitahu peserta didik yang kurang paham dan jika ada masalah yang tidak dapat terpecahkan, meminta bantuan kepada guru.

g. Penguatan dan kesimpulan secara bersama-sama

h. Melakukan pengamatan

i. Guru mengadakan evaluasi.

j. Pengisian angket

Pada pelaksanaan siklus II ini tampak sekali bahwa siswa sangat antusias dalam mengerjakan tugas kelompok, semua siswa terlihat aktif bersama kelompoknya dalam menyelesaikan tugas yang diberikan oleh peneliti. Berdasarkan hasil evaluasi yang telah dilaksanakan dan dikoreksi didaptkan hasil yang sesuai dengan indikator pencapaian hasil yang diharapkan, karena dari 40 siswa kelas XI AP 4 seluruhnya siswa mampu mendapatkan nilai sesuai KKM atau tuntas dan bahkan banyak siswa yang mencapai nilai di atas KKM dengan predikat sangat baik dan baik, sehingga prosentasi siswa yang telah tuntas adalah $100 \%$

Dari hasil evaluasi yang telah diberikan ternyata seluruhnya siswa mampu mendapatkan nilai sesuai KKM atau tuntas dan bahkan banyak siswa yang mencapai nilai di atas KKM. Pemahaman belajar siswa secara keseluruhan telah sesuai dengan yang diharapkan oleh peneliti karena dalam materi jenis - jenis kamar, siswa aktif berdiskusi bersama teman kelompoknya.

Pada setiap siklus diberikan angket terhadap motivasi belajar siswa sebagai alat untuk mengetahui tingkat keterlibatan siswa dalam kegiatan pembelajaran. Keterlibatan siswa dalam kegiatan pembelajaran dapat mempengaruhi motivasi belajar siswa terhadap materi pelajaran.

Berdasarkan analisis data motivasi belajar siswa pada siklus I diperoleh prsosentase jumlah motivasi belajar siswa yang termasuk kategori sangat tinggi sebesar $15 \%$. Kategori tinggi sebesar $45 \%$. Kategori sedang sebesar $40 \%$. Tidak ada kategori rendah dan sangat rendah. Secara umum motivasi belajar pada siklus I sudah sesuai dengan yang diharapkan dalam penelitian ini yaitu berada pada kategori sangat tinggi dan tinggi, namun masih ada beberapa hal yang perlu ditingkatkan dilihat dari kendalakendala pada hasil angket yang didapatkan.

Motivasi belajar siswa terlihat meningkat pada siklus II. Hal ini terbukti dari hasil analisis data yakni: motivasi belajar siswa yang termasuk kategori sangat tinggi sebesar $22.5 \%$. Kategori tinggi sebesar $65 \%$. Kategori sedang sebesar $12.5 \%$. Tidak ada kategori rendah dan sangat rendah. Secara umum motivasi belajar pada siklus II sudah sesuai dengan yang diharapkan dalam penelitian ini yaitu berada pada kategori sangat tinggi dan tinggi.

Untuk mengetahui tingkat pemahaman siswa terhadap materi yang dipelajarinya, guru memberikan test pemahaman materi. Berdasarkan test pemahaman materi yang diberikan pada siklus I didapatkan hasil bahwa ada 15 orang siswa (37.5\%) mendapatkan nilai dengan predikat sangat baik, 8 orang siswa (20\%) dengan nilai predikat baik, 14 orang siswa (35\%) dengan nilai predikat cukup, 2 orang siswa (5\%) dengan nilai predikat kurang dan 1 orang siswa $(2.5 \%)$ dengan nilai predikat sangat kurang. Jadi berdasarkan tabel diatas yang sudah tuntas dalam belajar baru mencapai 23 orang, siswa yang belum tuntas dalam belajar mencapai 17 orang dengan perolehan nilai rata - rata 77.85.

Pada siklus II terlihat bahwa pemahaman materi siswa meningkat. Hal ini terbukti dari hasil analisis yang telah dilakukan yakni: ada 25 orang siswa (62.5\%) mendapatkan nilai dengan predikat sangat baik, 15 orang siswa $(37.5 \%)$ dengan nilai predikat baik, tidak ada yang mendapatkan predikat cukup, kurang maupun sangat kurang. Pembelajaran sudah dilaksanakan lebih baik dan ada peningkatan, siswa yang sudah tuntas dalam belajar meningkat menjadi $100 \%$ yaitu 40 orang, tidak ada siswa yang belum tuntas dalam belajar. Dengan perolehan rata - rata 92.3. 


\section{PENUTUP \\ Simpulan}

Berdasarkan hasil penelitian yang telah dilaksanakan, maka dapat disimpulkan bahwa motivasi belajar siswa dalam mata pelajaran memproses reservasi dengan penerapan metode pembelajaran kooperatif berbantuan media game puzzle meningkat, hal ini dapat dilihat dari hasil yang telah dilakukan pada siklus I persentase jumlah motivasi belajar siswa motivasi yang termasuk kategori sangat tinggi sebesar $15 \%$. Menjadi $22.5 \%$ pada siklus II. Kategori tinggi sebesar $45 \%$, menjadi $65 \%$. Kategori sedang sebesar $40 \%$ menjadi $12.5 \%$ pada siklus II. Hal ini menunjukkan bahawa motivasi belajar siswa sudah semakin meningkat.

Data hasil pemahaman belajar siswa menunjukkan bahwa pemahaman belajar siswa kegiatan pembelajaran pada siklus I belum mengalami peningkatan, ada 15 orang siswa $(37.5 \%)$ mendapatkan nilai dengan predikat sangat baik, 8 orang siswa $(20 \%)$ dengan nilai predikat baik, 14 orang siswa $(35 \%)$ dengan nilai predikat cukup, 2 orang siswa $(5 \%)$ dengan nilai predikat kurang dan 1 orang siswa $(2.5 \%)$ dengan nilai predikat sangat kurang. Jadi berdasarkan tabel diatas yang sudah tuntas dalam belajar baru mencapai 23 orang, siswa yang belum tuntas dalam belajar mencapai 17 orang dengan persentase nilai rata - rata $77.85 \%$. Pada siklus II dengan persentase nilai rata - rata skor $92.3 \%$. Jadi dengan penerapan metode kooperatif berbantuan media game puzzle nilai rata - rata siswa meningkat $14.45 \%$

Saran

Berdasarkan penelitian yang telah dilaksanakan, peneliti mempunyai beberapa saran sebagai berikut.

1. Siswa kelas XI AP 4 SMK Negeri 2 Singaraja semester ganjil tahun pelajaran 2016/2017 menunjukkan tanggapan yang baik setelah dilaksanakan metode kooperatif berbantuan media game puzzle. Melihat hal tersebut peneliti menyarankan kepada guru untuk menggunakan metode kooperatif berbantuan media game puzzle sebagai salah satu alternatif pembelajaran memproses reservasi selanjutnya.

2. Jika menggunakan metode kooperatif berbantuan media game puzzle maka dibutuhkan perencanaan yang baik dan pengelolaan waktu yang tepat.

3. Sebelum menerapkan metode kooperatif berbantuan media game puzzle, terlebih dahulu guru harus mempersiapkan administrasi yang lengkap.

\section{DAFTAR PUSTAKA}

Arikunto, Suharsimi. 2006. Prosedur Penelitian Suatu Pendekatan Praktik. Jakarta: Rineka Cipta.

Corno, L., \& Mandinach, E. B. 1983. The Role of Cognitive Engagement in Classroom Learning and Motivation. Educational Psychologist, 18(2), 1-8

Daryanto. 2008. Evaluasi Pendidikan. Jakarta. Rineka Cipta.

Gunadi, Chintia Leo, William Gunawan. 2014. Hubungan Motivasi Akademik Dengan Prestasi Belajar Siswa Sma ' $\mathrm{X}$ ' Di Jakarta Barat. Jurnal NOETIC Psychology Volume 4 Nomor 1.

Kandoli, Louisa Nicolina. 2011. "Motivasi Dan Hubungannya Dengan Prestasi Belajar Mahasiswa Pada Mata Kuliah Tata Hidang Di Jurusan Pkk Fakultas Teknik." Jurnal Skripsi (tidak diterbitkan). Volume 2, Nomor 2 (hlm. 103). Tersedia pada http://pps.unj.ac.id/journal/jpd/ article/view/383 (diakses tanggal 2 Februari 2017).

Kementerian Pendidikan dan Kebudayaan Direktorat Jenderal Guru dan Tenaga Kependidikan, 2016. PANDUAN OPERASIONAL

PENYELENGGARAAN BIMBINGAN DAN KONSELING SEKOLAH MENENGAH PERTAMA (SMP). 
Nurdin. 2015. Hubungan Motivasi Belajar Terhadap Prestasi Belajar Pendidikan Kewarganegaraan. Faktor Jurnal Ilmiah Kependidikan Vol. II No. 2

Pintrich, Paul R \& Dale H. Schunk. 1996. Motivation in Education, Theory, Research, and Application. Ohio : Prentice Hall.

Pintrich, Paul R \& Schunk, Dale H. 2002. Motivation in Education : Theory,Research, and Applications2.Upper Saddle River. New Jersey : Merril Prentice Hall.

Pranomo, Wisnu Wibowo. 2014. Hubungan Motivasi Belajar Dengan Prestasi Belajar Siswa Kelas X Teknik Pemesinan Di Smk Antartika 1 Sidoarjo. JPTM, Volume 3 Nomor 1, Hal. $114-120$

Sanjaya, Wina. 2009. Strategi Pemebelajaran Berorientasi Standar Proses Pendidikan. Jakarta: Kencana.

Sardiman. 2007. Interaksi \& Motivasi Belajar Mengajar. Bandung: Raja Grafindo Persada.

Sri Susandi Ulandari, Komang. 2014. "Hubungan Antara Motivasi Belajar Dengan Prestasi Belajar Siswa SD Kelas V Semester Ganjil Di Desa Buruan." Jurnal Mimbar PGSD Universitas Pendidikan Ganesha. Volume 2, Nomor 1 (hlm. 119). Tersedia pada http://pps.unj.ac.id/journal/jpd/ article/view/383 (diakses tanggal 25 Februari 2017).

Winkel, W.S \& Sri Hastuti. 2006. Bimbingan dan Konseling di Institusi Pendidikan. Jakarta: PT. Grasindo.
2010. Bimbingan dan Konseling di Institusi Pendidikan. Jakarta: PT. Grasindo 